\title{
Food policy councils in the mid-Atlantic: Working toward justice
}

\author{
Sam Boden ${ }^{a *}$ and Brandon M. Hoover ${ }^{\mathrm{b}}$ \\ Messiah College
}

\begin{abstract}
Submitted July 9, 2017 / Revised September 19 and October 11, 2017 / Accepted October 31, 2017 /
Published online February 16, 2018

Citation: Boden, S., \& Hoover, B. M. (2018). Food policy councils in the mid-Atlantic: Working

toward justice. Journal of Agriculture, Food Systems, and Community Development, 8(1), 39-52.

https://doi.org/10.5304/jafscd.2018.081.002
\end{abstract}

Copyright (C) 2018 by the Authors. Published by the Lyson Center for Civic Agriculture and Food Systems. Open access under CC BY license.

\begin{abstract}
Moral political action within a food system is vital to human health and survival in the Anthropocene. Over the last 20 years, the alternative food movement has unpacked what that moral food system looks like, and how people either participate or are marginalized in various food systems. Largely overlooked in the alternative food discourse is the role of food policy councils (FPCs) in promoting, planning, and advocating for a regional food system that serves and supports its people.

Researchers at Johns Hopkins Center for a Livable Future put the number of FPCs in North America at 282 in 2015, a more than 650 percent increase over the previous decade (Johns Hopkins Center for a Livable Future, 2015). While the basic design of an FPC is often standard-a locally minded group of stakeholders recommending changes to food policy-the groups are often structured in

\footnotetext{
a * Corresponding author: Sam Boden, B.A., Sustainability Studies, Messiah College; samboden@rogers.com

${ }^{\mathrm{b}}$ Brandon M. Hoover, Director of Sustainability, Messiah College; bhoover@messiah.edu
}

different ways. This paper uses a mixed-methods approach, including participant interviews and website analysis, to study FPCs from the midAtlantic region of the United States and look at how their structure affects their emphasis on food justice. In an age of crippling food insecurity, dietrelated diseases, corporate hegemony, and food injustice, communities are looking for greater control of their regional food system; local FPCs can serve as a central hub for people to engage in food politics and enact change.

\section{Keywords}

Food Policy; Local Policy; Food Justice; Food Sovereignty; Community Development; Food Policy Councils

\section{Introduction and Literature Review}

The global food policy of recent decades could be described as a "race to the bottom," as governments apply amoral principles of neoliberalism in

\section{Author note}

This research was first presented at the American Association of Geographers conference in Boston, Mass., in April 2017. 
search of the cheapest places and ways to produce food, with little attention paid to the justice aspects of food production and distribution (Carolan, 2013). Food policy in the U.S. inhabits this description while also being incredibly complex; state and federal food policy processes require the cooperation and funding of numerous agencies and political operatives and are subject to the push and pull of competing private interests and public objectives (Wilde, 2013). In the midst of this jostling for food policy space, the voices of citizens are often unheard. This is problematic, as food issues like food insecurity - the inability to acquire nutritionally adequate and safe foods - remain a serious problem for many American. More than 12 percent of U.S. households are categorized as foodinsecure, including almost 5 percent as having "very low" food security (Coleman-Jensen, Rabbitt, Gregory, \& Singh, 2017). Additionally, the persistent dichotomy between America's urban and rural issues (roughly, the domestic food system's consumers and producers) is increasingly pronounced, which further isolates consumers from food policy that affects them (Franklin, Newton, \& McEntee, 2011; Pothukuchi \& Kaufman, 1999).

There has been, however, a recent shift of interest and purchasing of food to the local level as part of what many scholars call the "alternative food movement." The multifaceted alternative food movement is broadly defined as one working against corporate control of a food system, promoting local foods, developing civic-minded food producers and consumers, and working toward a just system for all producers and consumers (Alkon \& Norgaard, 2009; DeLind, 2011; Lyson, 2004). Composed of organizations like urban farms, farmers markets, food-related nonprofits and NGOs, and local food networks, the alternative food movement is having its cultural moment. One needs to look no further than the nearest Whole Foods grocery store, or even the grocery section in a Walmart, with their promotion of local, organic, or "natural" foods, to see how this phenomenon has gone mainstream.

Despite its cultural rise, the alternative food movement suffers from ideological deficiencies. Guthman (2011) describes the alt-food movement as more critical of what people eat ("healthism") than the injustices perpetuated in the food system. This movement also tends to be exceedingly white and wealthy, which is not reflective of the communities they seek to serve; it perpetuates an "affluent, liberal habitus of whiteness" (Alkon \& McCullen, 2010, p. 939). This is especially problematic as this movement purports to be something of a "people's revolution"; however, the means it employs are often exclusionary (Hinrichs \& Allen, 2008). The central themes of the alt-food movement promote ideological frameworks like the "100-mile diet," "voting with your fork," and "healthism," messages which encourage coexistence with unjust labor practices, institutional racism, and homogenized body imagery rather than working to change such practices (Alkon \& Norgaard, 2009; Guthman, 2011; Isenhour, 2011). Agyeman (2013) argues that localized food production and consumption are the means by which our society may achieve a more just food system, but we often confuse the ends with the means. Allen (2010) argues that consumer-based local food efforts are often so difficult to disentangle from the dominant political economy that they inadvertently reproduce social inequities.

As a response to the inequities in the alternative food movement, a focus on justice has been encouraged. Food justice is defined by Gottlieb and Joshi (2013) in distributive terms: "that the benefits and risks of where, what, and how food is grown and produced, transported and distributed, and accessed and eaten are shared fairly" (p. 6). There is also an evaluative component, as Allen (2010) argues that members of food movements must be willing to examine the forces that have configured the current food system and reflect upon which of their activities will move further toward social justice. Both the distributive and evaluative components of food justice must work in tandem to form a food justice movement. Ideally, food justice movements can create a political space for local citizens and encourage "policy from the ground up" (Wekerle, 2004, p. 382). One way in which this "policy from the ground up" can be encouraged is through food policy councils.

Food policy councils are, in many ways, the embodiment of food justice. While ideologically 
rooted in the alt-food movement, FPCs embrace a democratic participation model to encourage stakeholder involvement and amplify unheard voices. Purifoy (2014) argues that FPCs are the ideal institution to integrate the environmental and food justice movements at three critical points: public health and safety, ecological health, and social justice. FPCs are innovative, as their multisectoral composition contributes to their ability to pioneer programs, policy, and planning approaches that may not have been created without such collaborative efforts (Agyeman, 2013). One of their greatest democratic advantages is the ability to work on multiple policy levels, topics, and programs simultaneously (Scherb, Palmer, Frattaroli, 2012).

The literature on FPCs reflects this advantage; although much has been written in recent years, there are many facets of these democratic bodies that could be explored in greater detail. FPCs can be formed by legislation, executive orders, grassroots organizing, or as initiatives of nonprofit organizations (Harper, Shattuck, Holt-Giménez, Alkon, \& Lambrick, 2009). According to an American Planning Association report (DiLisio, 2011), they often share the same techniques for participation, including pursuing long-term strategies, offering tangible solutions, focusing on place-based activism, seeking government buy-in, and establishing formal membership structures. Generally, they fall into five categories of organization: independent coalitions, councils housed in government, councils embedded in universities, autonomous 501(c)(3) nonprofits, or part of larger nonprofit organizations. The focus of FPCs is diverse, and it can be challenging to pin down exactly what the roles of FPCs are, either in government or for the communities they serve. The primary concentration of FPCs is related to food access, but other areas of work may relate to land accessibility for growers (either urban or rural), urban agriculture zoning laws, nutrition, business development, and environmental issues related to agriculture. Most of the work of FPCs occurs at the city, institutional, and county levels; however, there are some that work at the state level (Coplen \& Cuneo, 2015; Fox, 2010; McClintock, Wooten, \& Brown, 2012; Scherb et al., 2012).

FPCs have experienced exponential growth in
America in recent decades, growing in number from about 27 in 2003 to over 200 active FPCs in 2016 (Sussman \& Bassarab, 2017). Despite their growth, however, they face many barriers to success after getting started (DiLisio, 2011; Scherb et el., 2012; Schiff, 2007). Their location inside or outside government is crucial. Proponents of ingovernment FPCs argue that such a situation provides the councils with legitimacy and the listening ear of policymakers, while critics say that independence from governments allows FPCs to critique their government more frankly (Fox, 2010). Keeping operational costs down is also a struggle, as many FPCs do not have a full-time staff person, relying instead on networks of volunteers, and grant funding is hard to come by (Center for a Livable Future, 2016). Most importantly for this discussion, different structures have been employed to varying levels of successin some cases, they have relied on strong mayoral systems to appoint members, worked hard to recruit government liaisons, leveraged their government connections to raise budget support, or focused on a number of different issues, not just hunger (Dahlberg, 1994; Schiff, 2008). It is also clear that FPCs without clear missions or cohesive communities are often susceptible to failure (Coplen \& Cuneo, 2014).

In sum: the food policy problem is clear, and the alternative food movement is an insufficient remedy. FPCs seek to reshape the alternative food movement by employing strategies of food justice, but the research on food policy councils is limited. What has yet to be explored, after accepting that food policy councils are adequate solutions to the injustices in food policy, is whether food policy councils reproduce the inequities evident in the alternative food movement. On paper, a food policy council engages stakeholders in systemic change for food justice, but is this true of FPCs in practice as well? More specifically, what is the relationship between an FPC's founding and organizing structure and its emphasis on justice?

It is this question on which this research is centered. A food-justice approach defines goals within a democratic framework and partners with the constituencies that the council seeks to represent, and a structural framework that 
encourages participation and partnership is essential to this approach (Clayton, Frattaroli, Palmer, \& Pollack, 2015; Hassanein, 2003). The concepts of food justice upon which this research is focused are taken from food-justice literature, and include Holt-Giménez (2009), Gottlieb and Joshi (2013), and Wekerle (2004): democracy, diversity, labor and production, retail and distribution, cultural appropriateness, and localness. Each concept is fundamental to the formation of a food-just FPC, is an aspirational goal of an FPC is working toward a focus on food justice, or is an issue overlooked completely by FPCs.

\section{Background on FPCs}

We focused on three FPCs in the mid-Atlantic region: the Adams County FPC, the Baltimore Food Policy Action Coalition (PAC), and the
Philadelphia Food Policy Advisory Council (FPAC). Their founding stories and different structures made them ideal case studies for understanding how structure might precede function. Their proximity to our location also made them reasonable choices. These groups are a testament to the fact that FPCs come in a variety of shapes and sizes, while all being centered on the cultivation of a new kind of people-centered food policy. Adams County FPC is located in Gettysburg, in the heart of what is regionally known as the "fruit belt" of Pennsylvania, where approximately $70 \%$ of Pennsylvania's apple crop is produced. Both Baltimore Food PAC and Philadelphia FPAC are in urban settings that suffer from food desertification and food access inequities. In Table 1 we detail the history and status, funding situation, participants and structure, and priorities of each group.

\section{Table 1. Background Information on Food Policy Council Subjects}

\begin{tabular}{|c|c|c|c|c|}
\hline & History and Status & Funding & Participants and Structure & Priorities \\
\hline $\begin{array}{l}\text { Adams County } \\
\text { Food Policy } \\
\text { Council }\end{array}$ & $\begin{array}{l}\text { Formed in } 2009 \text { by a proclamation } \\
\text { by the city commissioners. It is an } \\
\text { affiliated task force of the public- } \\
\text { private partnership Healthy Adams } \\
\text { County, which is administered by } \\
\text { county agencies and healthcare } \\
\text { providers like Wellspan Health. } \\
\text { Informal; has no } 501 \text { (c)(3) status. }\end{array}$ & $\begin{array}{l}\text { No consistent } \\
\text { funding; has } \\
\text { received } \\
\text { grant funding } \\
\text { for specific } \\
\text { programs. }\end{array}$ & $\begin{array}{l}\text { Largely composed of food } \\
\text { systems professionals from the } \\
\text { nonprofit sector. It has de facto } \\
\text { leadership, and new } \\
\text { participants can start attending } \\
\text { at any time. }\end{array}$ & $\begin{array}{l}\text { Focused mostly } \\
\text { on food-access } \\
\text { programs, work- } \\
\text { ing with local gro- } \\
\text { cery stores and } \\
\text { retailers who par- } \\
\text { ticipate in SNAP } \\
\text { (food stamps). }\end{array}$ \\
\hline $\begin{array}{l}\text { Baltimore } \\
\text { Food Policy } \\
\text { Action } \\
\text { Coalition }\end{array}$ & $\begin{array}{l}\text { Started in } 2010 \text { by the city's food } \\
\text { policy director as a part of the } \\
\text { Baltimore Food Policy Initiative, } \\
\text { which is an intergovernmental } \\
\text { collaboration between the Depart- } \\
\text { ment of Planning, Office of Sustain- } \\
\text { ability, City Health Department, and } \\
\text { Baltimore Development Corporation. } \\
\text { Embedded in government (meetings } \\
\text { occur in city planning office). }\end{array}$ & $\begin{array}{l}\text { Staff and } \\
\text { initiatives are } \\
\text { funded by the } \\
\text { city. }\end{array}$ & $\begin{array}{l}\text { Many food system professionals } \\
\text { (farmers, food access workers, } \\
\text { etc.) and academics are } \\
\text { represented. Led by city- } \\
\text { employed food planners, with } \\
\text { fully open meetings. Partici- } \\
\text { pants use a workshop model to } \\
\text { collaborate on policy and } \\
\text { program initiatives. }\end{array}$ & $\begin{array}{l}\text { Large focus on } \\
\text { retail and access } \\
\text { to healthy and } \\
\text { affordable food. } \\
\text { Networking is } \\
\text { also a priority of } \\
\text { the participants. }\end{array}$ \\
\hline $\begin{array}{l}\text { Philadelphia } \\
\text { Food Policy } \\
\text { Advisory } \\
\text { Council }\end{array}$ & $\begin{array}{l}\text { Established in } 2011 \text { by then-Mayor } \\
\text { Nutter, as recommended in the } \\
\text { Philadelphia Food Charter. It is an } \\
\text { advisory council to the mayor on } \\
\text { food policy issues. }\end{array}$ & $\begin{array}{l}\text { Its one staff } \\
\text { member } \\
\text { (FPAC coor- } \\
\text { dinator) is } \\
\text { funded by the } \\
\text { city. }\end{array}$ & $\begin{array}{l}\text { Appointed members (mostly } \\
\text { food system professionals) are } \\
\text { nominated by current members } \\
\text { and confirmed by the mayor's } \\
\text { office (no nominee has been } \\
\text { denied). Ex officio members are } \\
\text { on the FPAC as a function of } \\
\text { their role in city government. } \\
\text { Eight subcommittees guide the } \\
\text { focus of the group. The FPAC } \\
\text { coordinator leads meetings with } \\
\text { the appointed and ex officio } \\
\text { chairs. }\end{array}$ & $\begin{array}{l}\text { Focus on urban } \\
\text { agriculture, "good } \\
\text { food" } \\
\text { procurement, } \\
\text { food access. }\end{array}$ \\
\hline
\end{tabular}




\section{Adams County FPC mission statement:}

"In the interest of health and sustainability, The Adams County Food Policy Council promotes the integration of the individual, community, the economy, and the environment. We engage with businesses, institutions, social service agencies, community members, the agricultural sector, and government to develop food policy and take action." (Adams County FPC, n.d.-a, para. 3)

\section{Baltimore Food PAC mission statement:}

"Baltimore Food Policy Initiative and Food PAC collaborate to increase access to healthy, affordable food in Baltimore City food deserts by addressing health, economic, and environmental disparities." (Baltimore Office of Sustainability, 2016, p. 2)

\section{Philadelphia FPAC mission statement:}

"The Philadelphia Food Policy Advisory Council connects Philadelphians and their local government to create a more just food system. (Philadelphia FPAC, n.d.-a, para. 1)

\section{Applied Methods}

We used a mixed-methods approach, engaging participants in interviews and focus groups and attending meetings, as well as conducting a content analysis of the FPCs' websites, meeting minutes, and foundational documents, coding for specific concepts related to food justice. These methods were chosen because the quantitative results of the content analysis could be measured up against the qualitative testimony of the interviewees. In the months of February and March 2017, we engaged in participant observation by attending one general meeting of each group (an "executive" meeting of Philadelphia FPAC, which is open to the public, but the discussion is tailored more for leaders within FPAC). We aimed to conduct focus groups with all FPCs; however, due to time constraints, we were only able to conduct a focus group with
Adams County FPC (eight members). During the meetings of the Philadelphia FPAC and the Baltimore Food PAC, we put out an open call to participants who were interested in interviewing for our research and followed up with phone interviews (four from each).

The interviews and focus group followed a semistructured layout, with a consistent list of questions framed around food justice that also allowed the interviewer freedom to pursue lines of questioning that opened up according to participants' views. We interviewed a self-selected sample from each FPC, including people who were recent additions and those who were long-time members, as well as people in leadership positions. We asked questions about origin and structure, recruitment, and policy and program priorities. (For a full list of questions see the Appendix.)

We recorded all of our interviews and analyzed the conversations based on essential concepts of food justice from our research: democracy, diversity, labor and production, retail and distribution, cultural appropriateness, and localness. We determined that the presence of these factors was necessary to a just FPC. The mentions or lack of attention paid to certain topics were ruled as indicative of the FPCs' emphases on food justice. We relied heavily on interviewees' self-reporting on their FPCs' structure, composition, and recruitment techniques.

After the interviews were completed, the content analysis was coded based on the frequency of the following terms: justice, democracy, diversity, inclusion, stakeholders, "culturally appropriate," wages, workers, local, land, growers, and retail. Because websites represent a public presence of these FPCs, the frequency of these concepts' appearance on their websites is one indication of how the FPCs represent themselves. We sampled eight webpages from each group, 24 total ("About" pages, informational posts, foundational documents, member information, etc.), and all of the meeting minutes from 2016. This data was then compared with the testimony from the interviews to gauge FPCs' priorities.

\section{Findings}

Our sample represents three types of food policy 
councils: an informal, citizen-led coalition of mostly food system professionals working on programs; an open networking and policy advising group led by city food planners, catering mostly to food systems professionals; and a highly structured city advisory council led by appointed members. Our research seeks to explore whether these different structures influence or determine justiceoriented work. Based on the literature review, we identified six areas of food justice to explore in relation to food policy councils: democracy, diversity, labor and production, retail and distribution, cultural appropriateness, and localness. The findings will be explained along these concepts. Each of these categories has an enormous amount of crossover with the others, as they all reflect the idea of justice and point toward a holistic view of food justice. The presence of these concepts (or lack thereof) indicates the justice orientation of each group.

\section{Democracy}

Taking a wider view of food policy, ideally food policy councils stand alone as islands of democracy in an oligarchic food production and distribution environment. As discussed in the introduction, food policy at every level has often been entirely devoid of citizen participation, while FPCs seek to create and advise "policy from the ground up" (Wekerle, 2004, p. 382). All three FPCs placed a clear emphasis on group participation, and the leaders (both formal and informal) were highly accessible. Each leader described his or her group as led by the will of the people who make up the group-a claim backed up by the responses of the participants. There was a shared emphasis on democratization in all FPCs, insofar as they valued members' input and provided space for every member to share.

Some members of the councils reported that they were limited by weak relationships with policymakers. For example, the manager of the Philadelphia FPAC reported that although the group was a part of city government and was an advisory council to the mayor, it had not actually had a chance to offer policy recommendations to the FPAC-initiating mayor until the end of his term, nor had it yet been given the opportunity to meet with the new mayor. (In the time since this research was conducted, the Philadelphia FPAC has had a meeting with the mayor to offer policy advice and recommendations.) Members of other FPCs, such as those in the independent Adams County FPC, reported that freedom from policymakers was an advantage, as it gave them the opportunity to advocate freely and remain unburdened by government regulations.

The inclusion of constituents affected by food justice problems was a professed struggle for the three FPCs we surveyed, as nearly every interviewee reported that they wanted more low-income and minority community members to join their councils. Adams County FPC, for example, identified a paradox: the people who work in the applepicking industry in Adams County, many of whom are Hispanic, are the ones without access to healthy food. However, it did not have anyone on the council from the conventional food industry. The majority of FPC participants were food system professionals (those working in urban farming, food access, food policy, etc.), and of the people we talked to, more came from a professional food system background than those who were simply individual participants in the food system (nonfood system professionals). The Baltimore food planners, attempting to remedy the lack of stakeholders, have established a "Resident Food Equity Advisory," which is a group of community members who are paid to come in and share their views on food equity in order to educate the planners.

\section{"During a meeting of the Anti-Hunger subcommittee, we realized that no one at the table had experienced hunger." \\ —Philadelphia FPAC member}

\section{Diversity}

Diversity was a professed struggle for every group. As one member of the Baltimore Food PAC put it, "There are a lot of white people at the meetings, but it's mostly black people in [Baltimore] that experience food insecurity." It was clear that most of the people who attended the meetings of the three FPCs in our study were food system 
professionals, and the majority of those professionals were white, although the groups reported serving majority Hispanic and black communities. One Philadelphia FPAC member reported that their group was approximately $80 \%$ white and $10 \%$ African American, based on internal surveys, and yet the city is roughly $45 \%$ white and $44 \%$ black, based on U.S. Census data.

"Most people at the table are white and upperclass... while they mean well and have the theory, they need some reality."

—Racial minority member of Philadelphia FPAC

Skewed racial representation was a pervasive theme, but a lack of ideological diversity was often mentioned as well. For example, Adams County FPC does not include any conventional farmers, who are key members of the community and would arguably provide an alternative perspective on food issues. Adams County FPC members reported, however, that they would like to recruit more farmers, in the same way that members of Baltimore Food PAC and Philadelphia FPAC expressed a strong desire to make their groups less white.

"Sometimes [Baltimore Food PAC] feels like the 'yes, and...' club because everyone has bought in [to the group's goals] so much. Without friction, it's hard to innovate."

\section{- Member of Baltimore Food PAC}

In order to fully understand the racial and ideological makeup of these FPCs, we must establish an understanding of their recruitment practices. All three groups relied primarily on word of mouth and member recommendations for recruitment. Both Baltimore Food PAC and Adams County FPC have an informal membership structure, wherein anyone can attend and consider themselves a member. Philadelphia FPAC has a formal nomination process, where people are nominated (or self-nominate) to join the group, their applications are considered, and the mayor's office appoints members for specified terms. (No nominee affirmed by FPAC has ever been denied by the mayor's office.)

"A lot of recruitment happens within nested circles of contacts."

—Member of Philadelphia FPAC

\section{Labor and Production}

In our interviews and content analysis, there was little discussion of equity in food production or laborers' rights. (For our purposes, "laborers" are those working at any point in the food systemharvesting, distribution, food retail, and food service.) The only laborers mentioned were those in urban food production; except for a few mentions of urban farmers, there were no references to food production or food laborers as policy priorities, nor were there any food laborers in the conventional food system at the meetings in which we participated. While the urban nature of all three FPCs explains our findings (as of this writing, Adams County FPC primarily serves the needs of residents of the city of Gettysburg, rather than the farmers and laborers of rural Adams County), a foodjustice approach requires that FPCs provide holistic support of people involved at all stages of the food system. As we reported in the "Democracy" section, members of Adams County FPC expressed a desire to recruit farmers more intentionally.

Although the interviews with Philadelphia FPAC did not display an emphasis on labor and production, it addresses these issues through its Workforce and Economic Development subcommittee. According to the website, this subcommittee works to create a "food system in which workers along the entire food chain enjoy quality jobs that provide economic stability and upward mobility" (Philadelphia FPAC, n.d.-d, para. 1). Additionally, Philadelphia FPAC's Good Food Procurement subcommittee's definition of good food includes that which is "produced by fair labor" (Philadelphia FPAC, n.d.-b, para. 3). These mentions indicate that Philadelphia FPAC, through its subcommittees, is considering the rights of 
workers proactively. The FPCs did have a focus on local food production and the urban agricultural labor that supported it, and many members of the FPCs were engaged in urban agriculture.

\section{Retail and Distribution}

All three FPCs considered food access issues to be top priorities. When asked what their FPC's top three priorities were, almost every respondent said food access or food security. Adams County FPC, for example, was led by the paradox that many of the pickers employed in the fruit belt do not have access to fresh fruits and vegetables. To remedy this, Adams County FPC works with individual local grocery stores to encourage healthy options. It employs methods such as encouraging local grocery stores and farmers markets to accept food assistance programs, advocating against price hikes at the beginning of each month (when SNAP beneficiaries have more to spend), and doubling SNAP benefits for healthier foods.

\section{"This is a bugely agricultural region, but people aren't getting the food that's produced here."}

- Member of Adams County FPC

Baltimore Food PAC, through the Baltimore Food Policy Initiative, employs a Food Desert Retail Strategy that uses five approaches for encouraging food retail in limited supermarket access areas: attract and retain grocery stores, improve nontraditional grocery options, increase healthy food availability in market settings, address gaps in transportation that affect access, and support innovative strategies to amplify the food economy. The other groups did not have this kind of detailed, policy-focused strategy to address food access issues.

Buying locally produced food was also important to the groups, especially Adams County FPC and Philadelphia FPAC. Adams County FPC has a local foods guide, which is put out periodically on behalf of the FPC, and Philadelphia FPAC promotes the "Philly Food Finder" and "Good Food Guide." These are program-based strategies for encouraging retail and distribution of local food.
Food access programs are a key aspect of food justice, and all three FPCs emphasized food access to varying degrees.

\section{Cultural Appropriateness}

Cultural appropriateness naturally follows from democracy and stakeholder inclusion. The groups reported a sustained interest in designing culturally appropriate solutions to food system problems, but struggled to achieve these goals because their inclusion of affected constituents was limited. Because those constituents were not always included, it was hard to gauge the cultural appropriateness of the FPCs' solutions. However, Philadelphia FPAC's website provides an insight into the desire that FPCs have to address this concept of food justice: "We envision that all Philadelphians can access and afford healthy, sustainable, culturally appropriate, local, and fair food" (Philadelphia FPAC, n.d.-c, para. 1).

\section{Localness}

Although "local" was not often explicitly mentioned in the FPC interviews, most of the answers were locally situated and provided a clear picture of localness as a priority. That is, the FPC participants were passionate about keeping food production and spending within the region as much as possible. For example, the second-listed goal on Adams County FPC's website is to "strengthen [the] local economy by supporting and promoting local farmers and businesses" (Adams County FPC, n.d.-b, "Our Goals," para. 2). This seemed to be a shared goal among all three FPCs, especially as the groups were largely composed of members of locally based food and agriculture groups. Local farmers markets and food pantries were well represented in the meetings we attended.

\section{Content Analysis for FPC Websites}

After completing the interviews we conducted a content analysis (Figure 1), coding for the concepts listed below. The analysis had its limitations, as the frequency of concepts does not necessarily mean operationalization, and as we were unable to analyze every webpage due to time constraints, choosing instead to sample eight webpages from each FPC's website. However, the websites are the main 
Figure 1. Results from Content Analysis for FPC Websites

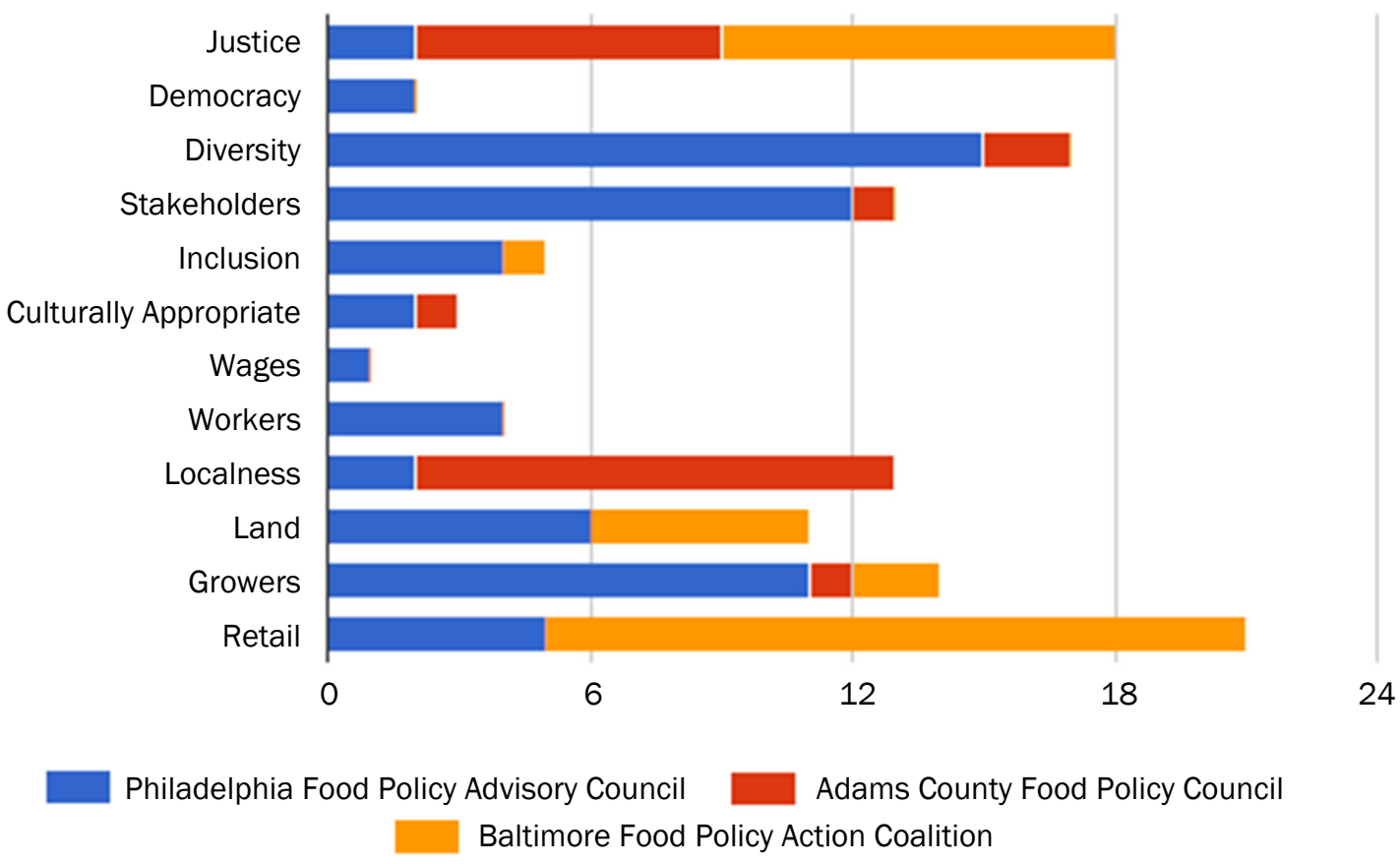

public-facing tool for FPC outreach, so the communications they include are essential to understanding the FPCs' focuses and accessibility. The emphasis on concepts such as "diversity" and "stakeholders" proved that although the FPCs struggled in these areas, their own websites promote an aspirational vision. The lesser emphasis on wages, workers, and cultural appropriateness is appropriate, given the results of the interviews.

\section{Discussion and Applicability}

It is important to situate this discussion in an understanding of the breadth of good work that these three FPCs do for their communities. While this research undertakes a critical analysis of three differently structured food policy councils, it is crucial to reiterate that these groups have an exceedingly positive impact on their communities through food access programs, food retail strategy, and policy advising. We hope that the findings and discussion in this research serve as guideposts for constructing more just FPCs.

While all three FPCs were engaging in models of democratic participation, they struggled with including the voices of all those affected by food- system problems. Inherent within the concepts of diversity and democracy is the inclusion of affected constituents; this is arguably the most important aspect of justice for FPCs. A locally based FPC that does not represent the values, concerns, or views of its locality is merely an alt-food discussion group. Troublingly, there was a clear lack of stakeholder participation reported by many interviewees, and neither open recruitment (as practiced by Baltimore Food PAC and Adams County FPC) nor the combination of appointments and ex officio membership (Philadelphia FPAC) was especially conducive to the inclusion of stakeholders.

Moreover, there was not a targeted effort to recruit from underrepresented groups, specifically underrepresented persons who are also stakeholders in the success of the FPCs' programs and policy advising. The FPCs declined to utilize proactive recruitment techniques, preferring to encourage recruitment by word of mouth and website and social media posts. In contrast, more stakeholder participation could likely be encouraged by engaging in some form of proactive recruitment or membership structuring process. Possible strategies include targeted recruitment campaigns in specific 
neighborhoods and quotas for neighborhood representatives that must be satisfied within the FPCs' member composition. Baltimore's Resident Food Equity Advisory facilitates the involvement of a representative from each council district; such a practice could be reproduced in a variety of ways to encourage participation of underrepresented persons.

All three FPCs struggled from a lack of diversity-mostly economic, racial, and gender diversity. All the groups were majority white, composed largely of food system professionals; while this composition made the groups helpful for the professional networking of their members, such a makeup arguably skews the purpose of a food policy council. This is troubling because the majority of communities in which the FPCs worked were composed of mostly minority ethnic groups. Moreover, the groups seemed to feel the blinding effects of ideological homogeneity, as participants reported that their FPC discussions lacked the clarifying power of disagreement. A key principle of food justice is incorporating and allowing ideological differences in the pursuit of equity; what truly catalyzes democracy is the presence of various perspectives and identities (Gottlieb \& Joshi, p. 229).

This diversity problem likely can be traced back to the recruitment practices of the groups, as they reported recruiting from "nested circles of contacts" and through word of mouth. This type of recruitment is antithetical to diversity, as members may unintentionally recruit and nominate people similar to themselves. Many members also discussed how much they valued the networking capacity of their FPCs, which brings up the question: what would encourage people to recruit members who do not offer benefits from a "networking" perspective? Thus it is unsurprising that many of the FPCs' members looked similar to each other and shared similar views on food and justice.

Additionally, two of the FPCs suffered from weaker links to policymakers, which made it harder for their democratic successes to reach their full potential. FPCs must exist within a political framework in order for their democratic achievements to be attainable. Philadelphia FPAC reported that their only meeting with their first mayor had been at the end of his term. (They have met with the new mayor since this research was conducted.) Adams County FPC had county planners on the council but no formalized policy recommendation process, choosing instead to focus on programming. While it is valuable to enact food programs through democratic engagement, failing to offer policy recommendations makes it more difficult to fully embody the principles of food justice because it addresses only certain issues (e.g., healthy options for SNAP beneficiaries) rather than seeking to change policies which perpetuate unjust systems.

It seems clear that an FPC structure with direct links to the government can enact comprehensive food-system change more easily. Although, as ACFPC members pointed out, governmentembedded FPCs have much less leeway because of official regulations, that embeddedness establishes a direct link with the policymaking bodies. Without a connection to food policymakers, food democracy does not transcend the confines of the FPC and thus necessarily falls short of its goal to change policy. Baltimore Food PAC offered a possible template for a healthy government link, as it is led by food planners and the food policy director, who are responsible for making food policy decisions for the city; furthermore, that structure provides an arena for citizen advocacy, as the planners are put in the room with the people they serve.

There are other structural recommendations to be gleaned from these findings. Regarding cultural appropriateness, there are advantages to the subcommittee structure employed by Philadelphia FPAC in designing culturally appropriate solutions. Each of the subcommittees is "laser-focused" on its issue, as one member put it, which allows them to examine the issue from a variety of angles and, arguably, to tailor remedies specifically to the communities. These subcommittees are formed based on the interests and passions of the FPC participants. While the lack of stakeholder inclusion made it difficult to assess the relationship between FPCs' structure and their emphasis on this aspect of food justice, subcommittees could be targeted toward food justice areas that are often overlooked, such as labor and production. (It is essential that these committees do not merely pay 
lip service to overlooked issues; the committees designed to tackle issues must be robust and well supported.) The lack of intersectionality in this structure is disadvantageous, however, as the same member said, "all food issues are related to each other."

Baltimore Food PAC and ACFPC were both highly accessible and flexible on which members can work on issues, so they also have advantages for designing culturally appropriate solutions. Nevertheless, without the affected constituents represented in the FPCs, the groups will miss essential community feedback to tailor their solutions for cultural appropriateness. Community input is needed, as the knowledge of organizations will only go so far to prescribe relevant solutions, and without appropriate solutions, neither an FPC's programs nor its policies will be sustainable.

We found that localness was a priority for the groups, as it was threaded through many of the answers we received, including discussions of urban agriculture. Because local food and "buying local" are now in the mainstream alternative-food movement, their inclusion in the food policy councils' work is not necessarily indicative of an emphasis on food justice. Moreover, FPCs are inherently local, as they are generally designed to trumpet the voice of the people in their locality; we are concerned with which voices are being trumpeted. As of this writing, essential constituent voices may be missing from the table.

Thus, each of the three food policy councils was employing food justice strategies in some significant ways, and had work to do in other areas. All of the FPCs need to address their lack of diversity and stakeholder participation, as these problems are central to the mission of an FPC. The best way to address these problems is likely through reforming recruitment strategies and proactively seeking stakeholder engagement. Strong links to policymakers-whether through leadership from city employees (like Baltimore Food PAC) or open lines of communication with policymakersseems to be essential to the success of FPCs' democratic goals. Additionally, employing a subcommittee structure that targets areas of food justice that are often overlooked-like retail and distribution — could be one of the most appropriate strategies for structuring an FPC to prioritize food justice issues.

There were significant limitations to this research, as scheduling conflicts proved to be prohibitive for the level of involvement we sought as researchers, and the time frame was rigid. However, these findings make it clear that much more research must be done on the structure of food policy councils and how they can prepare for success; as the number of FPCs continues to rise, careful application of best practices will become increasingly important.

\section{Conclusion}

The food policy councils we surveyed are making remarkable progress in the cities and county in which they worked. We were able to witness development in burgeoning food democracies, where people's voices were heard in the food policy process and could work for the betterment of their communities. Each group exemplified the power and practicability of the food justice movement, in spite of the areas in which the groups fell short. Our goal was to determine the relationship between FPCs' structure and their emphasis on food justice, and we were able to witness the ways in which the FPCs functioned and now offer recommendations for a more just future. We hope that the recommendations contained in this research will contribute to the fine-tuning of these groups and the formation of new, justice-oriented food policy councils.

\section{References}

Adams County Food Policy Council [FPC]. (n.d.-a). About us. Retrieved March 1, 2017, from

http://www.adamsfoodpolicy.org/About.html

Adams County FPC. (n.d.-b). What we do. Retrieved February 15, 2018, from

http://www.adamsfoodpolicy.org/What_We_Do.html

Agyeman. J. (2013). Introducing just sustainabilities: Policy, planning and practice. New York: Zed Books. 
Alkon, A. H., \& McCullen, C. G. (2011). Whiteness and farmers markets: Performances, perpetuations...Contestations? Antipode, 43(4), 937-959. https://doi.org/10.1111/j.1467-8330.2010.00818.x

Alkon, A. H., \& Norgaard, K. M. (2009). Breaking the food chains: An investigation of food justice activism. Sociological Inquiry, 79(3), 289-305. https://doi.org/10.1111/j.1475-682X.2009.00291.x

Allen, P. (2010). Realizing justice in local food systems. Cambridge Journal of Regions, Economy, and Society, 3(2), 295-308. https://doi.org/10.1093/cjres/rsq015

Baltimore Office of Sustainability. (2016). Baltimore Food Policy Initiative (BFPI): Organizational structure. Retrieved from http://www.baltimoresustainability.org/wp-content/uploads/2015/03/BFPI-Overview-Food-PAC-12.05.16.pdf

Carolan, M. S. (2013). Reclaiming food security. New York: Routledge.

Clayton M. L., Frattaroli, S., Palmer A., \& Pollack, K. M. (2015). The role of partnerships in U.S. food policy council policy activities. PLoS ONE, 10(4), e0122870. https://doi.org/10.1371/journal.pone.0122870

Coleman-Jensen, A., Rabbitt, M. P., Gregory, C., \& Singh, A. (2017). Household food security in the United States in 2016 (USDA-ERS Report No. 237). Retrieved from USDA-ERS website: https://www.ers.usda.gov/publications/pubdetails $/$ ?pubid $=84972$

Coplen, A. K., \& Cuneo, M. (2015). Dissolved: Lessons learned from the Portland Multnomah Food Policy Council. Journal of Agriculture, Food Systems, and Community Development, 5(2), 91-107. https://doi.org/10.5304/jafscd.2015.052.002

Dahlberg, K. (1994, June). Food policy councils: The experience of five cities and one county. Paper presented at the Joint Meeting of the Agriculture Food and Human Values Society and the Association for the Study of Food and Society, Tucson, Arizona.

DeLind, L. B. (2011). Are local food and the local food movement taking us where we want to go? Or are we hitching our wagons to the wrong stars? Agriculture and Human Values, 28(2), 273-283. https://doi.org/10.1007/s10460-010$\underline{9263-0}$

DiLisio, C. (2011). Food policy councils: Helping local, regional, and state governments address food system challenges. Chicago: American Planning Association. Retrieved from https://www.jhsph.edu/research/centers-and-institutes/johnshopkins-center-for-a-livable-future/pdf/projects/FPN/Urban Community Planning/APA FOOD SYSTEM PLANNING BRIEFING PAPER.pdf

Fox, C. (2010). Food policy councils: Innovations in democratic governance for a sustainable and equitable food system. Retrieved from https://goodfoodlosangeles.files.wordpress.com/2011/01/fpc_final_dist-5-indd.pdf

Franklin, A., Newton, J., \& McEntee, J. C. (2011). Moving beyond the alternative: Sustainable communities, rural resilience and the mainstreaming of local food. Local Environment, 16(8), 771-788. https://doi.org/10.1080/13549839.2011.574685

Gottlieb, R., \& Joshi, A. (2013). Food justice. Cambridge, Massachusetts: MIT Press.

Guthman, J. (2011). Weighing in: Obesity, food justice, and the limits of capitalism. Berkeley: University of California Press. Harper, A., Shattuck, A., Holt-Giménez, E. Alkon, A., \& Lambrick, F. (2009). Food Policy Councils: Lessons learned (Development Report No. 21). Retrieved from Food First website: https://foodfirst.org/publication/food-policycouncils-lessons-learned/

Hassanein, N. (2003) Practicing food democracy: A pragmatic politics of transformation. Journal of Rural Studies, 19(1), 77-86. https://doi.org/10.1016/S0743-0167(02)00041-4

Hinrichs, C. C., \& Allen, P. (2008). Selective patronage and social justice: Local food consumer campaigns in historical context. Journal of Agriculture and Environmental Ethics, 21(4), 329-352. https://doi.org/10.1007/s10806-008-9089-6

Holt-Giménez, E. (2009). From food crisis to food sovereignty: The challenge of social movements. Monthly Review, 61(3). https://doi.org/10.14452/MR-061-03-2009-07_11

Isenhour, C. (2011). Can consumer demand deliver sustainable food?: Recent research in sustainable consumption policy and practice. Environment and Society, 2(1), 5-28. https://doi.org/10.3167/ares.2011.020102

Johns Hopkins Center for a Livable Future. (2015). Food policy councils in North America: 2015 trends. Retrieved from http://www.foodpolicynetworks.org/food-policy-resources/?resource $=834$ 
Lyson, T. A. (2004). Civic agriculture: Reconnecting farm, food, and community. Lebanon, N.H.: University Press of New England.

McClintock, N., Wooten, H., \& Brown, A. H. (2012). Toward a food policy "first step" in Oakland, California: A food policy council's efforts to promote urban agriculture zoning. Journal of Agriculture, Food Systems, and Community Development, 2(4), 15-42. https://doi.org/10.5304/jafscd.2012.024.009

Philadelphia Food Policy Advisory Council [FPAC]. (n.d.-a). About. Retrieved March 1, 2017, from https://phillyfpac.org/about/

Philadelphia FPAC. (n.d.-b). Good food procurement. Retrieved March 25, 2017, from https://phillyfpac.org/subcommittees/good-food-procurement/

Philadelphia FPAC. (n.d.-c). Home. Retrieved March 1, 2017, from https://phillyfpac.org/

Philadelphia FPAC. (n.d.-d). Workforce \& economic development. Retrieved March 25, 2017, from https://phillyfpac.org/workforce-economic-development/

Pothukuchi, K., \& Kaufman, J. L. (1999). Placing the food system on the urban agenda: The role of municipal institutions in food systems planning. Agriculture and Human Values, 16(2), 213-224. https://doi.org/10.1023/A:1007558805953

Purifoy, D. M. (2014). Food policy councils: Integrating food justice and environmental justice. Duke Environmental Law and Policy Forum, 24(2-3), 375-398. Retrieved from https://scholarship.law.duke.edu/delpf/vol24/iss2/3/

Scherb, A., Palmer, A., Frattaroli, S., \& Pollack, K. (2012). Exploring food system policy: A survey of food policy councils in the United States. Journal of Agriculture, Food Systems, and Community Development, 2(4), 3-14. https://doi.org/10.5304/jafscd.2012.024.007

Schiff, R. (2007). Food policy councils: An examination of organisational structure, process, and contribution to alternative food movements (Doctoral dissertation). Retrieved from http://researchrepository.murdoch.edu.au/id/eprint/293/

Schiff, R. (2008). The role of food policy councils in developing sustainable food systems. Journal of Hunger \& Environmental Nutrition, 3(2-3), 206-228. https://doi.org/10.1080/19320240802244017

Wekerle, G. R. (2004). Food justice movements: Policy, planning, and networks. Journal of Planning Education and Research, 23(4), 378-386. https://doi.org/10.1177/0739456X04264886

Wilde, P. (2013). Food policy in the United States: An introduction. New York: Routledge. 


\section{Appendix. Interview Questions}

1. How did your FPC start?

2. Can you explain the structure of your FPC? For example: its relationship with government, membership structure, existence of subcommittees, leadership structure, etc.?

3. Are members recruited or appointed by your FPC?

4. What is the member composition?

5. What are the main challenges that your FPC faces?

6. What do you consider to be your food policy council's 3 top priorities?

7. Who would you consider a primary partner in achieving your mission and priorities?

8. Who are the primary stakeholders in the success of your food policy council initiatives?

9. Does the general public participate in your meetings?

a. What ways do you actively promote your meetings?

10. How do you learn about and represent the concerns of the public?

11. How do the interests of members influence the direction of the FPC? 